\title{
DEVELOPMENT OF INTERACTIVE MULTIMEDIA USING THE MACROMEDIA FLASH AND SCIENCE APPROACH FOR ENGINEERING MATERIALS COURSES IN MECHANICAL ENGINEERING EDUCATION UNIVERSITAS SRIWIJAYA
}

\author{
Imam Syofii ${ }^{1}$, Rukiyah ${ }^{2}$, Dewi Puspita Sari ${ }^{1 *}$ \\ ${ }^{1}$ Study Program of Mechanical Engineering Education, Universitas Sriwijaya, Indralaya - 30662, South \\ Sumatera, Indonesia
}

${ }^{2}$ Study Program of Early Childhood, Universitas Sriwijaya, Indralaya - 30662, South Sumatera, Indonesia

\begin{abstract}
This study aims to developing interactive multimedia using Macromedia Flash and science approach for Engineering Materials courses in study program of Mechanical Engineering Education, Universitas Sriwijaya. The Macromedia flash was used because run easily on a computer or laptop without supporting applications (user friendly). While science approach was used because Engineering Material course are science based. The development of interactive multimedia was used the Rowntree method. The Rowntree method has three stage: planning; development and evaluation. Based on results, interactive multimedia using Macromedia flash and science approach are valid with percentage of $83 \%$ for multimedia and $75.58 \%$ for matters, practice with percentage in small group test of $86 \%$, and effective with percentage in field test of $100 \%$. Thus, the interactive multimedia that has been developed is recommended for use in study program of Mechanical Engineering Education, Universitas Sriwijaya.
\end{abstract}

Keywords: Interactive Multimedia, Engineering Materials Course, Education, Macromedia flash, Science approach

\section{INTRODUCTION}

Learning process is an interaction process between tutors with student. A good learning process occurs if has a systematic learning program, where them has a strategy so that results of learning is good and measurable [1]. Utilization of technology is something that should be done so that learning strategies become effective [2]. The choice of learning method determines the success of the transfer knowledge from tutor to students. For science course, a scientific approach is considered appropriate to be applied because it adapts the steps of the scientific process namely inductive reasoning [3][4]. The advantages learning process using the science approach is it create students attitudes, skills and knowledge through scientific concepts [5].

Engineering Material course in study program of Mechanical Engineering Education, Universitas Sriwijaya are science based. This course provides matters about materials for mechanical engineering. The course matters are properties and testing of engineering materials, metal alloy of steel and cast iron and or stainless steel, corrosion, polymeric materials, ceramics materials, and future materials. These matters are difficult to transfer if using discourse, presentation or question and answer method. This is because more than $60 \%$ of student difficulties in this course. The learning process using interactive multimedia the science approach is good choice for the matters is transferred properly.

Multimedia is a combination of types of media, where it is a combination of text, graphics, animation, sound and or images [6]. The multimedia is made interactive for learning to be interesting or called interactive multimedia [7]. Macromedia Flash is a software that is often to create learning media, no exception interactive multimedia. Since the results of Macromedia flash is a program that can be run easily on a computer or laptop without supporting applications. Thus, this study tries to integrate science approaches

*Corresponding author's email: dewipuspita@ fkip.unsri.ac.id 
with interactive multimedia for Engineering Materials course. The interactive multimedia is built using Macromedia Flash.

In the education tertiary especially, it also can not escape from the 4.0 industrial revolution development. The Education Law mandates that a university not only conduct academic activities but also carry out Academic Quality Assurance (AQA) to maintain and improve the quality of higher education. In a planned and sustainable manner, which conducted through the establishment, implementation, evaluation, control, and improvement of the standards of Higher Education. Based on the similarity of the concepts of PQA and AQA, this study will design and apply web-based AQA in Mechanical Engineering Department Sriwijaya University following the standards of the National Accreditation Agency for Higher Education (BAN-PT) in 2019.

Design web-based student information management system, one centralized database via the internet technology, The principal data collection methods were questionnaires and follow up interviews, The quantitative data collected were analyzed and presented using Microsoft Excel Package, The system benefits students as it has cut the time spent during registration periods in every new semester [8].

Design of a Multifunctional Web Portal for College Departmental Activities, Keeping and maintaining online records have become vital, a Website has become an essential requirement, design, and build a Web portal for the college department. This Web portal will consist of various interlinked web pages comprising of several types of information and activities; Crucially, it serves to reduce the communication gap between the faculty and the students, to accomplish this using the latest scripting technologies like HTML, CSS, javascript, and PHP [9].

The QA system will work as providing users the required NCAAA (National Commission for Academic Accreditation and Assessment) reports' forms to be filled. Then, the proposed QA system will gather forms and generates completed reports, and at the same time, it provides them to the decision-makers. The proposed QA system will allow decision-makers to approve reports and view gathered information in many aspects in which will facilitate the making decision processes in continuous improvement of the educational processes and outcomes, Based on the functionality of the proposed QA system, the architecture that will be used is Client/Server architecture using the "Client/Server Model".

There are three layers that composed together, which are: client layer, server layer, and the data layer. The client layer contains the interface which will be implemented in the proposed QA system by HTML and java scripts languages and for the user to request a process from the server layer we will use an ASP.net language.

On the other hand, the server layer will handle the request by performing an SQL query and retrieve the data from data layer which contains the QA database such as equipment, staff and building data that will be stored in a relational database. Also, the QA database interacts with the relevant data files and responds to the requests. Moreover, Client/Server model selected because the proposed QA system is web-based system and this architecture excels in flexibility, easy to add new servers or upgrade existing servers and user independence, In conclusion, this project has achieved some features and functionalities that the QA system provides [10].

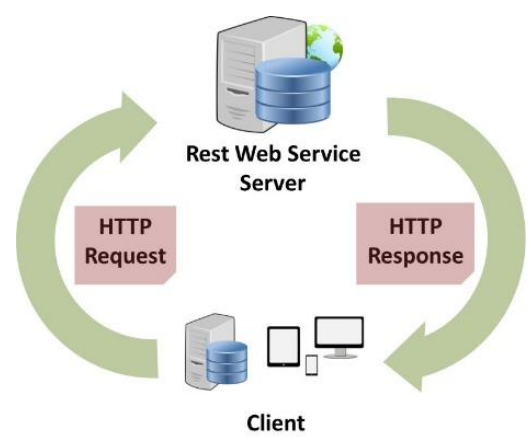

Figure 1 REST API architecture

\section{METHOD}

Development of interactive multimedia using Macromedia Flash was used the Rowntree method. the Rowntree method has three stage [11]: planning; development and evaluation. Planning is an analysis of needs and formulation of goals. Development is the preparation of material and making media. Evaluation is the improvement of matters and media.

Media and matters are said to be good if they are categorized as valid, effective, and interactive. Determination of valid, effective, and interactive using the Equation 1. 


$$
\begin{aligned}
& \text { Percentage }(\%)= \\
& \frac{\text { observation results }}{\text { maximum score }} \times 100 \%
\end{aligned}
$$

After that, the calculation results using Equation 1 are categorized using Table 1. Furthermore, media and matters are categorized as effective and practice if $70 \%$ of students have grades about 56 .

Table 1. Description value

\begin{tabular}{ll}
\hline Percentage & Interpret \\
\hline $76-100 \%$ & Valid \\
$56-75 \%$ & Enough \\
$40-55 \%$ & Less \\
$0-39 \%$ & Not \\
\hline
\end{tabular}

The development and evaluation stage are a combination activity. The activity has three phases: one to one test (3 respondents); small group test (10 respondents); and field test (one class or 40 respondents).

\section{RESULTS AND DISCUSSIONS}

Media dan matters that have been generated into interactive multimedia are called prototype 1 . Based on expert assessment, the matters used obtained a score of $75.58 \%$, categorized as valid. While, for media obtained score of $83 \%$, categorized as valid too. Based on these results, the prototype 1 deemed appropriate to the next

Based on one to one test, respondent's response it there are no obstacles in understanding the matters and running prototype 1 . This indicates the prototype 1 eligible to the next phase. Based on small group test with 10 respondents, the percentage of practice of prototype 1 of $86 \%$, categorized as practice. Respondents suggest prototype 1 was used for the next course activity. In addition, respondents in small group test give advice for prototype 1 using bright colours but not contrast. Prior to the next phase, prototype 1 was improved based on respondents in small group test called prototype 2 .

The next is field test. The difference between the field test stage and the others is that the pretest and post-test are prepared. Based on pre-test, $52.5 \%$ of 40 respondents has score with enough categorized (56 to $60 \%$ ), $40 \%$ has values with less categorized (41 to $55 \%$ ), and $7.5 \%$ with not understand categorized (0 to 40\%). Based on field test (post-test), $27.5 \%$ of respondents has values with very good categorized (86 to $100 \%$ ), and
$42.5 \%$ with good categorized (71 to $85 \%$ ), and $30 \%$ with enough categorized (56 to $70 \%$ ).

\section{CONCLUSIONS}

Development of interactive multimedia using Macromedia Flash and science approach for Engineering Materials courses in study program of Mechanical Engineering Education, Universitas Sriwijaya are valid with percentage of $83 \%$ for multimedia and $75.58 \%$ for matters, practice with percentage in small group test of $86 \%$, and effective with percentage in field test of $100 \%$. Thus, the interactive multimedia that has been developed is recommended for use in study program of Mechanical Engineering Education, Universitas Sriwijaya.

\section{ACKNOWLEDGEMENT}

This work was supported by the Institute of Research and Community Service (LPPM) Universitas Sriwijaya with grant No: 0009/UN9/SK.LP2M.PT/2018.

\section{REFERENCES}

[1] A. Suharsimi and C. S. A. Jabar, Evaluasi Program Pendidikan. 2009.

[2] S. Sukiman, Pengembangan Media Pembelajaran (Yogyakarta: Pedagogia). 2012.

[3] I. Maryani and L. Fatmawati, Pendekatan scientific dalam pembelajaran di sekolah dasar: teori dan praktik. Deepublish, 2018.

[4] M. Muhammad and N. Nurdyansyah, "Pendekatan Pembelajaran Saintifik." Nizamia Learning Center, 2015.

[5] A. R. Setiawan, "Penerapan Pendekatan Saintifik Dalam Pembelajaran Biologi Sebagai Upaya Melatih Literasi Saintifik Siswa Sekolah Menengah,” 2019.

[6] A. Muhson, "Pengembangan Media Pembelajaran Berbasis Teknologi Informasi," Jurnal Pendidikan Akuntansi Indonesia, vol. 8, no. 2, 2010.

[7] Daryanto, Media pembelajaran. 2010.

[8] S. Lubanga, W. Chawinga, S. Kapondera, and R. Holloway, "Web Based Student Information Management System in Universities: Experiences from Mzuzu University," in Standing Conference of Eastern, Central and Southern Africa Library and Information Associations 
(SCESCAL), May 2018A, Uganda, 2018, no. May, pp. 655-669.

[9] O. S. Vaidya and T. Bakshi, "Design of a Multifunctional Web Portal for College Departmental Activities," Internationa Research Journal of Engineering and Technology (IRJET), vol. 4, no. 5, pp. $2127-$ 2132, 2017.

[10] S. A. El_Rahman and B. A. Al-Twaim, "Development of Quality Assurance System for Academic Programs and Courses Reports," International Journal of Modern Education and Computer Science, vol. 7, no. 6, pp. 30-36, 2015, doi: 10.5815/ijmecs.2015.06.05.

[11] D. S. Prawiradilaga, Prinsip Desain Pembelajaran, II. Jakarta: Kencana Prenada Media Group, 2007. 